\title{
Domestic water demand forecasting in the Yellow River basin under changing environment
}

\author{
Xiao-jun Wang, Jian-yun Zhang, Shamsuddin Shahid, Lang Yu, \\ Chen Xie, Bing-xuan Wang and Xu Zhang \\ (Author affiliations can be found at the end of the article)
}

\section{Domestic water demand forecasting}

Received 17 March 2017 Revised 15 June 2017 17 July 2017

15 August 2017

Accepted 17 September 2017

\begin{abstract}
Purpose - The purpose of this paper is to develop a statistical-based model to forecast future domestic water demand in the context of climate change, population growth and technological development in Yellow River.

Design/methodology/approach - The model is developed through the analysis of the effects of climate variables and population on domestic water use in eight sub-basins of the Yellow River. The model is then used to forecast water demand under different environment change scenarios.

Findings - The model projected an increase in domestic water demand in the Yellow River basin in the range of $67.85 \times 10^{8}$ to $62.20 \times 10^{8} \mathrm{~m}^{3}$ in year 2020 and between $73.32 \times 10^{8}$ and $89.27 \times 10^{8} \mathrm{~m}^{3}$ in year 2030 . The general circulation model Beijing Normal University-Earth System Model (BNU-ESM) predicted the highest increase in water demand in both 2020 and 2030, while Centre National de Recherches Meteorologiques Climate Model v.5 (CNRM-CM5) and Model for Interdisciplinary Research on Climate- Earth System (MIROC-ESM) projected the lowest increase in demand in 2020 and 2030, respectively. The fastest growth in water demand is found in the region where water demand is already very high, which may cause serious water shortage and conflicts among water users.

Originality/value - The simple regression-based domestic water demand model proposed in the study can be used for rapid evaluation of possible changes in domestic water demand due to environmental changes to aid in adaptation and mitigation planning.
\end{abstract}

Keywords Climate change, Statistical model, Water demand forecasting,

Water resources management, Yellow river

Paper type Research paper

\section{Introduction}

Climate change, rapid social economic development and population growth have imposed significant challenges to sustainable development all around the world (Nigel and Ben, 2014, Wang et al., 2014a, 2014b; Shahid et al., 2014, 2016). As a unique and increasingly scarce commodity, water is among the most significantly affected resources by these changes. Ensuring continuous and adequate water supply to growing population and developing economy is one of

(C) Xiao-jun Wang, Jian-yun Zhang, Shamsuddin Shahid, Lang Yu, Chen Xie, Bing-xuan Wang and $\mathrm{Xu}$ Zhang. Published by Emerald Publishing Limited. This article is published under the Creative Commons Attribution (CC BY 4.0) licence. Anyone may reproduce, distribute, translate and create derivative works of this article (for both commercial \& non-commercial purposes), subject to full attribution to the original publication and authors. The full terms of this licence may be seen at http:// creativecommons.org/licences/by/4.0/legalcode
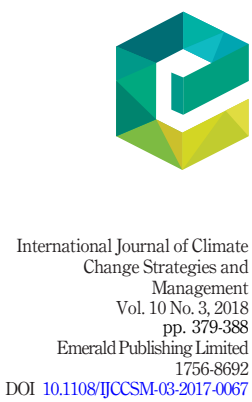
IJCCSM

10,3

\section{0}

the major concerns for policy makers and scientists (Butler and Memon, 2006; Kim et al., 2014). It is much more challenging in arid and semi-arid river basins in Australia, Middle East, Africa and Northern China due to limited availability of water resources (Howe et al., 2005; Butler and Memon, 2006; Wang et al, 2012a). Understanding possible future changes in water demand is essential for the development of effective climate change adaptation policies (Shahid et al., 2017).

Water demand is influenced by various factors such as population growth, technological development, climate change, social-economic (Wang et al., 2016a). The complex interactions of different influential factors have made the forecasting of water demand a difficult task (Vörösmarty et al., 2000; Downing et al., 2003; Alvisi et al., 2003; Babel et al., 2007; Khatri and Vairavamoorthy, 2009; Wang et al., 2015). A number of studies have been carried out to predict water demand (Combalicer et al., 2010; Dursun, 2010; Jakimavičius and Kriaučiūnienè, 2013; Wang et al., 2016b). The approaches generally used for forecasting water demand can be classified into three broad classes, namely, time series, econometric and end-use forecasting (Zhou et al., 2000; Alvisi et al., 2003; Altukaynak et al., 2005; Bougadis et al., 2005; Khatri and Vairavamoorthy, 2009; Caiado, 2010; Wang et al., 2017). Besides that, artificial neural network, support vector regression, etc. have been used in a few cases (Ghiassi et al., 2008; Adamowski, 2008). Unfortunately, yet only a few of the traditional forecasting models can adequately manage the dynamics of a water supply system because of the limitations in modeling structures. Potential challenges also arise, as these traditional methods require long-term, continuous historical records of water demand and other variables (Simonovic, 2002; Qi and Chang, 2011).

The impact of climate change on water demand is a major issue in recent years. Most of the recent studies on climate change impacts on water demand are based on the historical relationship between water demand and climate variables such as rainfall, air temperature, sunshine duration, relative humidity and wind speed (Protopapas et al., 2000; Downing et al., 2003; Karamouz et al., 2011). It is widely accepted that water demand will increase due to the increased evapotranspiration caused by higher temperature. However, how to take consideration of climate variables and population growth together for forecasting future domestic water demand is still a challenge.

The Yellow River, originated in the Qinghai-Tibetan plateau of Qinghai province, flows across eight other provinces and autonomous regions of China before it ends into the Bohai Sea (Liu and Zhang, 2002; Wang et al., 2012b). The river plays a key role not only in the country's economic development, but also in the historic and cultural identity of the Chinese people. With approximately 9 per cent of China's population and 17 per cent of its agricultural area depending on the Yellow River basin, it is designated as "the cradle of Chinese Civilization" (Liu and Zhang, 2002; Giordano et al., 2004). Population and economy of the River Basin have grown rapidly in the recent years. This has caused a significant increase in water demand for agriculture, industry and households in the Basin. Consequently, the gap between water supply and demand has widened in recent years (Giordano et al., 2004; Barnett et al., 2006; Gonçalves et al., 2007). Some of the main tributaries of the Yellow River, such as Kuye River and Tuwei River, showed a decreasing trend of runoff, even drying up (Wang et al., 2014b). Increase in demand of water for domestic use due to climate change and population growth may aggravate the existing situation of water shortage in the Basin. Forecasting possible changes in residential water demand is very important for planning and management of water resources of the Basin.

The objective of the present paper is to develop a statistical model to forecast domestic water demand in the context of climate change, population growth and technological development. The proposed model is developed through the analysis of the effects of climate and population on domestic water use and then applied in the Yellow River basin to forecast water demand under different environment change scenarios. 


\section{Materials and methods}

\subsection{Data and sources}

2.1.1 Water consumption and population growth data. Population growth, domestic water use and economic development data of the Yellow River basin for the period 1980-2012 were collected from China Water Resources Bulletins (MWR, 2000-2012). The recent data of domestic water use in eight sub-basins of the Yellow River, namely, Uperstream of Longyangxia (UL), LongyangxiaLanzhou (LL), Lanzhou-Hekouzhen (LH), Hekouzhen-Longmen (HL), Longmen-Sanmenxia (LS), Sanmenxia-Huayuankou (SH), Downstream of Huayuankou (DH) and Interior Area (IA), were collected from the Yellow River Water Resources Bulletins (YRCC, 1998-2012). Table I summarizes the basic statistics of collected data for different sub-basins of the Yellow River.

2.1.2 Meteorological data. Daily temperature data of 61 stations for the period 1961-2012 were obtained from National Climate Center of China (NCCC). Climate projections by a suit of seven general circulation models (GCMs), namely, Beijing Climate Center-Climate System Model version 1 (BCC-CSM1-1), BNU-ESM, CNRM-CM5, Goddard Institute for Space Studies Model E version 2 with Russell ocean model (GISS-E2-R), MIROC-ESM, Max Planck Institute-Earth System Model-Low Resolution (MPI-ESM-LR) and Meteorological Research Institute-Coupled Global Climate Model version 3 (MRI-CGCM3), under Representative Concentration Pathways (RCPs) scenario RCP4.5 were also collected from NCCC.

\subsection{Domestic water demand forecast modeling}

Domestic water demand includes water needs for all residential purposes such as in-house water use for drinking, preparing food, bathing, washing clothes and dishes and flushing toilets, etc. as well as outdoor water needs for gardening, lawn watering, etc. (Alvisi et al., 2003; Garcia et al., 2004; Blokker et al., 2010; Wang et al., 2017). According to the water resources planning technical specifications of China, domestic water demand and population growth can be linked through the following equations:

$$
\begin{aligned}
L W^{\prime} & =L u W^{\prime}+L r W^{\prime} \\
& =P u^{\prime} \times L Q u^{\prime} \times \frac{365}{1000}+P r^{\prime} \times L Q r^{\prime} \times \frac{365}{1000}
\end{aligned}
$$

\begin{tabular}{|c|c|c|c|c|c|c|c|}
\hline \multirow[b]{2}{*}{ Sub-basin } & \multirow{2}{*}{$\begin{array}{c}\text { Area } \\
\left(10^{4} \mathrm{~km}^{2}\right)\end{array}$} & \multicolumn{5}{|c|}{$\begin{array}{l}\text { Population } \\
\left(10^{4} \mathrm{p}\right) \text { in } 2010\end{array}$} & \\
\hline & & $(1956-2000)$ & Urban & Rural & in 2010 & $\left(\mathrm{P} / \mathrm{km}^{2}\right)$ in 2010 & \\
\hline Yellow River & 79.5 & 445.8 & 4543.27 & 6824.96 & 40.0 & 143 & \\
\hline UL & 13.1 & 478.3 & 14.28 & 50.95 & 21.9 & 5 & \\
\hline LL & 9.1 & 478.9 & 327.12 & 590.29 & 35.7 & 101 & \\
\hline LH & 16.3 & 261.9 & 850.36 & 755.62 & 52.9 & 99 & \\
\hline $\mathrm{HL}$ & 11.2 & 433.5 & 265.02 & 605.98 & 30.4 & 78 & Table I. \\
\hline LS & 19.2 & 540.6 & 2066.34 & 3053.14 & 40.4 & 268 & Climate and \\
\hline $\mathrm{SH}$ & 4.2 & 659.5 & 529.66 & 810.61 & 39.5 & 319 & population of \\
\hline DH & 2.2 & 647.8 & 463.68 & 928.22 & 33.3 & 633 & different sub-basins \\
\hline IA & 4.2 & 271.9 & 26.81 & 30.15 & 47.1 & 14 & of the Yellow River \\
\hline
\end{tabular}


IJCCSM

10,3

\section{2}

Figure 1.

Historical and projected change in population in different sub-basins of the Yellow River where $L W$ is the domestic water demand $\left(10^{4} \mathrm{~m}^{3}\right)$, which can be estimated by multiplying the projected population $\left(10^{4} \mathrm{p}\right)$ with the projected per capita water consumption (1/p.d). The urban water demand, $L u W^{\prime}$ is estimated by multiplying the urban population, $P u^{\prime}\left(10^{4} \mathrm{p}\right)$, with the per capita water consumption by urban population, $L Q u^{\prime}(1 /$ p.d); the rural water demand, $L r W^{\prime}$, is estimated by multiplying the rural population, $\operatorname{Pr}^{\prime}\left(10^{4} \mathrm{p}\right)$, with the per capita water consumption by rural population, $L Q r^{\prime}(1 /$ p.d) (Wang et al., 2011).

Equation (1) does not consider climate change for forecasting water demand. Therefore, the equation is modified in this study to incorporate the impact of climate change on water demand, $\Delta L W^{t}$, as follows:

$$
\Delta L W^{t}=d_{T} \cdot \Delta T \cdot L W^{t}
$$

where:

$$
d_{T}=\frac{\Delta L W}{\Delta T}
$$

where $d_{T}$ is the climatic elasticity of domestic water demand; $\Delta L W$ is the change in domestic water demand $\left(10^{4} \mathrm{~m}^{3}\right)$; and $\Delta T$ is the change in temperature $\left({ }^{\circ} \mathrm{C}\right)$.

\section{Domestic water demand under changing environment}

\subsection{Population growth and domestic water use}

The historical changes and future projection of population in different sub-basins of the Yellow River basin are shown in Figure 1. The highest population in the Yellow River basin is in LS subbasin, while the lowest population in UL sub-basin. Figure 1 shows that the population in all the sub-basins has increased rapidly over the past years. Population in the Yellow River basin was $8,177 \times 10^{4}$ in 1980 and the urbanization rate was only 17.8 per cent. The highest rate of urbanization was in LH (33.5 per cent). According to the future plan of River Basin management authority, the total population and urbanization in the Basin will reach 12,658 $\times 10^{4}$ and 50.4 per cent, respectively, in 2020 and 13,094 $\times 10^{4}$ and 58.8 per cent, respectively, in 2030 .

The growing population has caused a drastic increase in domestic water demand in the Basin. The domestic water consumption in the Yellow River basin has increased from $11.72 \times$ $10^{8} \mathrm{~m}^{3}$ in 1980 to $22.66 \times 10^{8} \mathrm{~m}^{3}$ in 2000 . The per capita water demand has also increased due to urbanization and changes in socioeconomic condition of the people. The changes in per capita domestic water demand in different sub-basins are shown in Figure 2. The figure shows

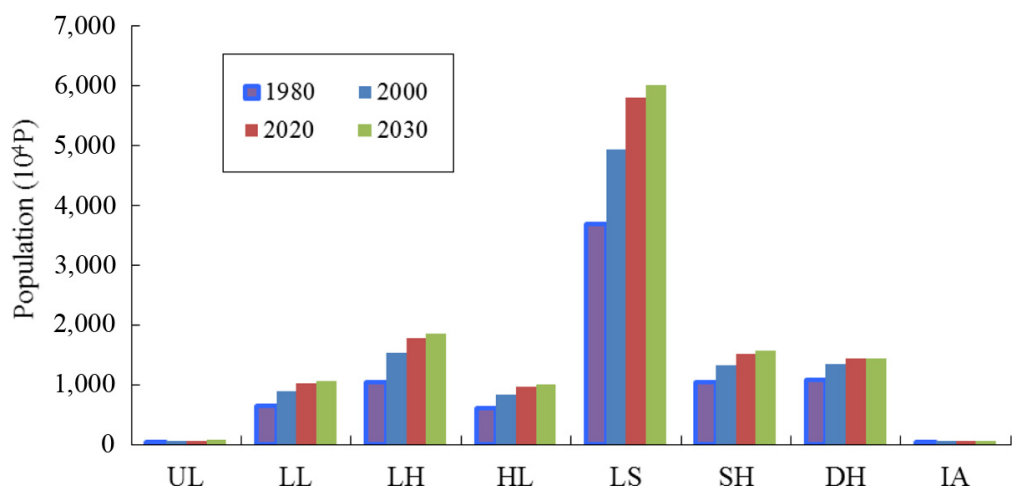


that the average per capita water consumption in the Basin has increased from only $73 \mathrm{l} / \mathrm{p} . \mathrm{d}$ in 1980 to 103 1/p.d in 2000. It has been projected that per capita water demand will continue to increase in the Basin and will reach 115 1/p.d and 123.7 1/p.d in 2020 and 2030, respectively.

\subsection{Projection of temperature}

The climate models projected increase in temperature, but no significant change in rainfall in the Yellow River basin. The projections of temperature by GCMs BCC-CSM1-1, BNUESM, CNRM-CM5, GISS-E2-R, MIROC-ESM, PI-ESM-LR, MRI-CGCM3 in the Yellow River basin are shown in Figure 3. The figure shows a increase in temperature before 2030. As there is no change in rainfall, only temperature was considered to assess the impact of climate change on water demand in the Basin.

\subsection{Domestic water demand due to climate change}

The ensemble mean of the projected temperatures by different GCMs was used to estimate future changes in water demand in the Yellow River basin due to climate change. The changes in residential water demand in different sub-basins due to climate change for the years 2020 and 2030 are shown in Figures 4 and 5, respectively. The figures show increase in water demand in all

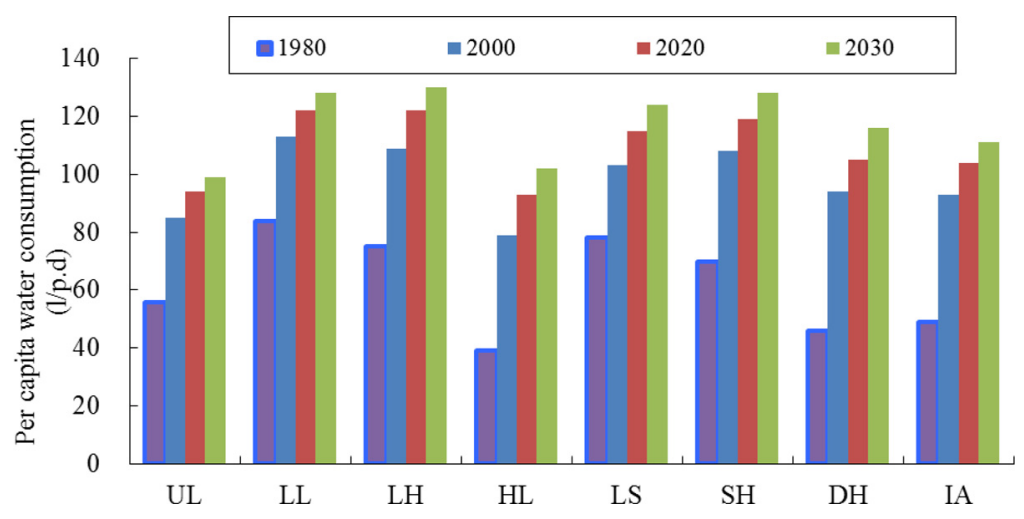

Figure 2. Changes in per capita water consumption in the Yellow River basin

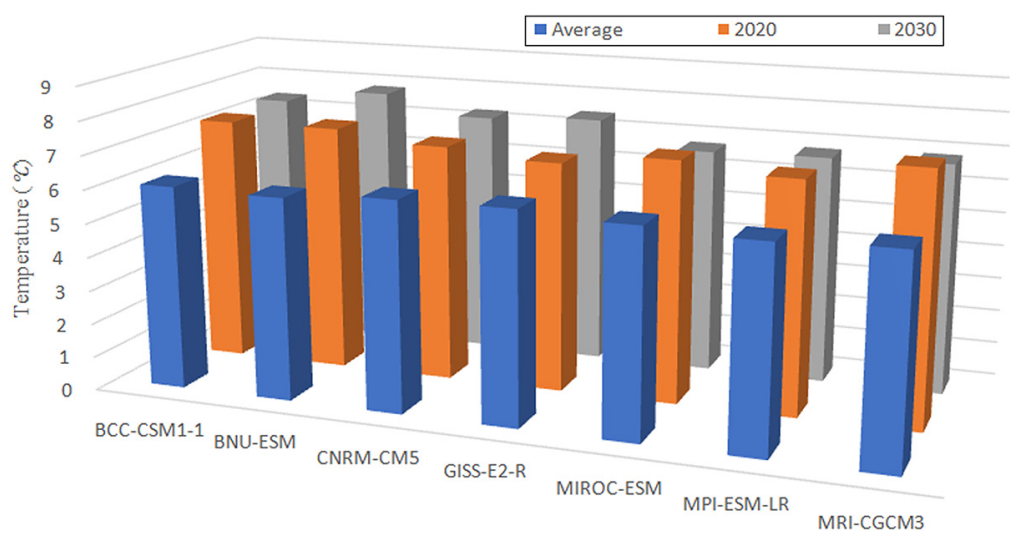

Figure 3.

Temperature projections by different GCMs in the Yellow River basin under RCP4.5 in 2020 and 2030 
IJCCSM

10,3

\section{4}

Figure 4.

Projected domestic water demand in year 2020 under RCP4.5

\section{Figure 5.}

Projected domestic water demand in year 2030 under RCP4.5 the regions of the Yellow River basin. The highest increase was observed in LS, followed by DH. Domestic water demand in LS is already very high due to large population. Faster increase in water demand due to climate change may aggregate the condition of water scarcity and conflict among water users in the region.

\subsection{Domestic water demand under changing environment}

The projected growth in population and the advancement in water-saving technologies were also considered along with climate change to forecast domestic water demand in the Yellow River basin. Equation (1) was used to estimate the impact of population growth and urbanization on domestic water demand. Reduction of water demand through the advancement of water-saving technologies as planned by the Yellow River basin authority was then incorporated to estimate the net changes in water demand. Figures 6 and 7 show the projected change in domestic water demand in 2020 and 2030, respectively, due to climate change, population growth and technological advancement together.

Figure 6 shows that domestic water demand will increase in the range of $67.85 \times 10^{8}$ to $62.20 \times$ $10^{8} \mathrm{~m}^{3}$ in 2020. The GCM BNU-ESM projected the highest increase, while CNRM-CM5 the lowest. The water demand was projected to increase in the range of $89.27 \times 10^{8}$ to $73.32 \times 10^{8} \mathrm{~m}^{3}$ in 2030 . The highest increase was projected by BNU-ESM and the lowest by MIROC-ESM. Among the SubBasins, the highest increase in water demand was projected in LS and the lowest in UL.

\section{Conclusion}

A statistical model was developed in this paper to forecast domestic water demand due to changes in climate, population and water-saving technologies. Results showed that
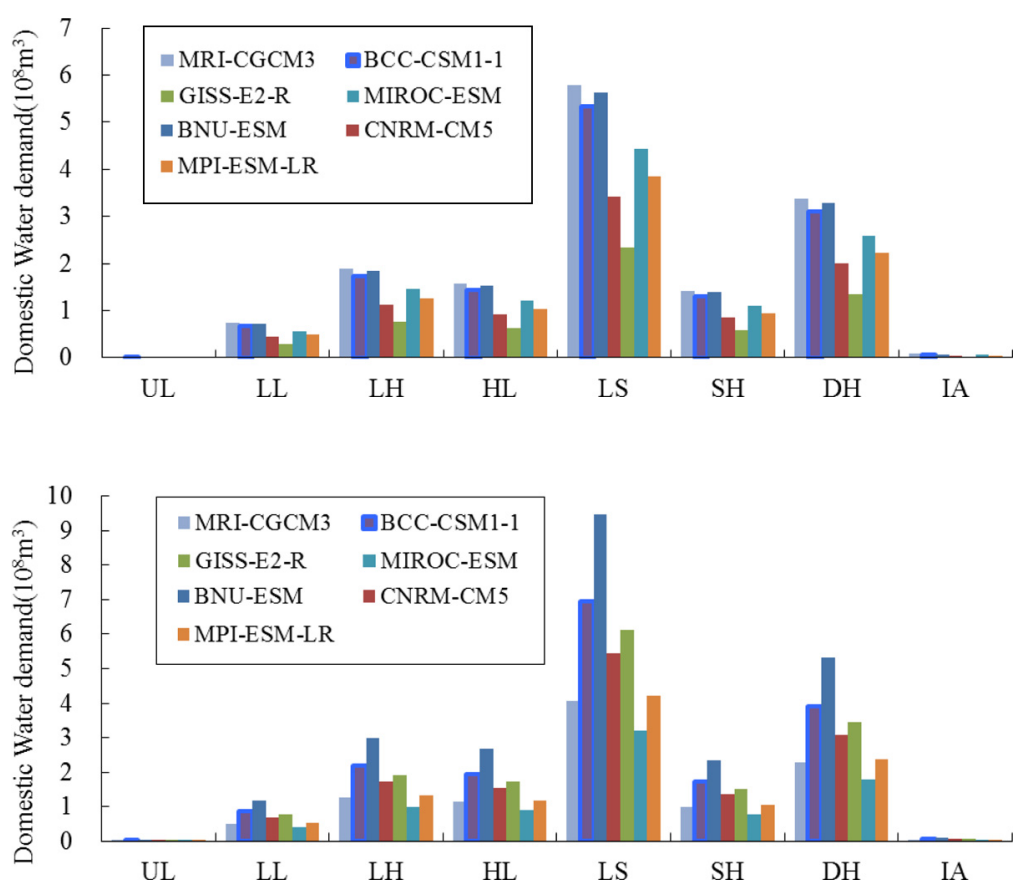
domestic water demand in the Basin will increase in the range of $67.85 \times 10^{8}$ to $62.20 \times$ $10^{8} \mathrm{~m}^{3}$ in 2020 and $89.27 \times 10^{8}$ to $73.32 \times 10^{8} \mathrm{~m}^{3}$ in 2030 . The highest increase will be in the LS and the lowest in UL. The LS is the most populated region of the Basin. High water demand due to large population has already made water in the Sub-Basin scarce. It can be anticipated that the rapid increase in water demand due to climate change and population growth will aggravate the situation in the future. It will also increase the competition among water users and, therefore, more conflicts.

The method proposed in the study can be used for rapid evaluation of possible changes in domestic water demand in the context of environmental changes. However, more attention is required for improvement of the method. Following points should be considered for future improvement of the model:

- domestic water demand for different in-house and outdoor activities are different and therefore, impacts of environmental changes on each activity should be evaluated for better projection of water demand;

- only the average temperature was considered to estimate the impacts of climate change on domestic water demand in this study and other climatic variables such as maximum and minimum temperature and humidity can be considered for the improvement of model accuracy; and

- furthermore, future study is required to assess uncertainties in water demand projection for better planning and management of water resources.

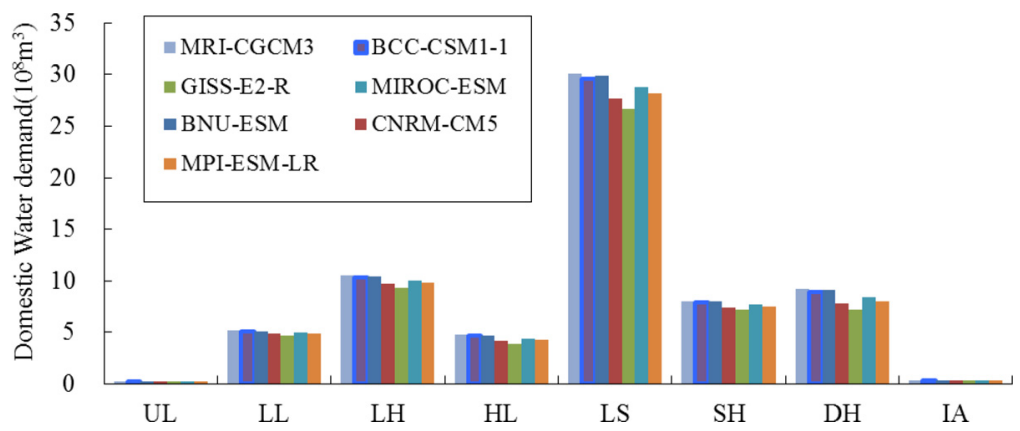

Figure 6.

Changes in domestic water demand in year

2020 due to environmental changes

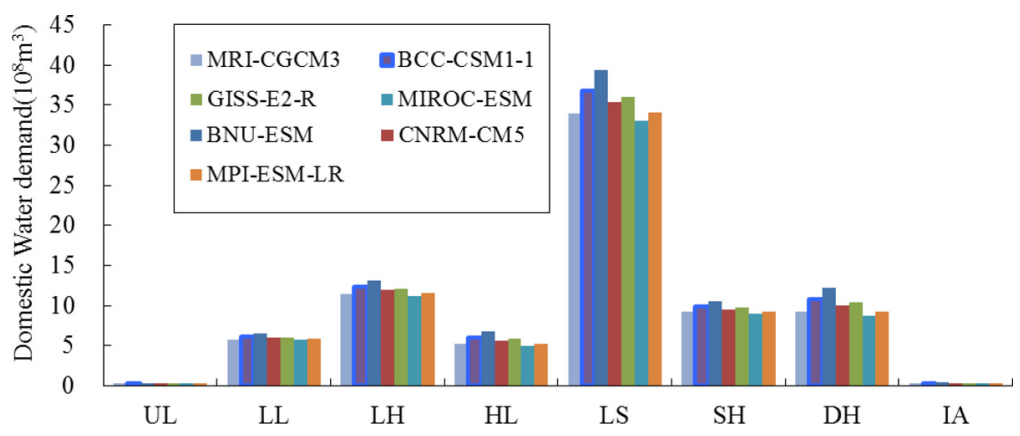

Figure 7.

Changes in domestic water demand in year

2030 due to environmental changes 


\section{IJCCSM 10,3}

\section{Acknowledgements}

The authors are grateful to the National Key R\&D Program of China (No. 2017YFC0403506), National Natural Science Foundation of China (No. 51309155), Strategic Consulting Projects of Chinese Academy of Engineering (No. 2016-ZD-08-05-02), China Water Resource Conservation and Protection Project (No. 126302001000150001) and Open Research Fund of State Key Laboratory of Simulation and Regulation of Water Cycle in River Basin China Institute of Water Resources and Hydropower Research (No. IWHR-SKL-201515) for providing financial support for this research. The authors are also thankful to anonymous reviewers and editors for their helpful comments and suggestions.

\section{References}

Adamowski, J.F. (2008), "Peak daily water demand forecast modeling using artificial neural networks", Journal of Water Resources Planning and Management, Vol. 134 No. 2, pp. 119-128.

Altukaynak, A.S., Özger, M. and Çakmakci, M. (2005), "Water consumption prediction of Istanbul city by using fuzzy logic approach”, Water Resources Management, Vol. 19 No. 5, pp. 641-654.

Alvisi, S., Franchini, M. and Marinelli, A. (2003), "A stochastic model for representing drinking water demand at residential level”, Water Resources Management, Vol. 17, pp. 197-222.

Babel, M.S., Das Gupta, A. and Pradhan, P. (2007), "A multivariate econometric approach for domestic water demand modeling: an application to Kathmandu, Nepal”, Water Resources Management, Vol. 21 No. 3, pp. 573-589.

Barnett, J., Webber, M. and Wang, M. (2006), "Ten key questions about the management of water in the yellow river basin”, Environmental Management, Vol. 38 No. 2, pp. 179-188.

Blokker, E.J.M., Vreeburg, J.H.G. and van Dijk, J.C. (2010), "Simulating residential water demand with a stochastic end-use model”, Journal of Water Resources Planning and Management, Vol. 136 No. 2, pp. 19-26.

Bougadis, J., Adamowski, K. and Diduch, R. (2005), "Short-term municipal water demand forecasting", Hydrological Processes, Vol. 19 No. 1, pp. 137-148.

Butler, D. and Memon, F.A. (2006), Water Demand Management, IWA Publishing, London.

Caiado, J. (2010), "Performance of combined double seasonal univariate time series models for forecasting water demand", Journal of Hydrologic Engineering, Vol. 15 No. 3, pp. 215-222.

Combalicer, E.A., Cruz, R.V.O., Lee, S. and Im, S. (2010), "Assessing climate change impacts on water balance in the mount Makiling Forest, Philippines", Journal of Earth System Science, Vol. 119 No. 3, pp. 265-283.

Downing, T.E., Butterfield, R.E. and Edmonds, B. (2003), "Climate change and the demand for water", Research Report, Stockholm Environment Institute Oxford Office, Oxford.

Dursun, S. (2010), "Effect of global climate change on water balance of Beyşehir lake (Konya - turkey)", Balwois 2010, Ohrid, Republic of Macedonia, 25-29 May 2010.

Garcia, V.J., Garcia-Bartual, R., Cabrera, E. and Arregui, F. (2004), "Stochastic model to evaluate residential water demands", Journal of Water Resources Planning and Management, Vol. 130 No. 5, pp. 386-394.

Ghiassi, M., Zimbra, D.K. and Saidane, H. (2008), "Urban water demand forecasting with a dynamic artificial neural network model”, Journal of Water Resources Planning and Management, Vol. 134 No. 4, pp. 138-146.

Giordano, M., Zhu, Z., Cai, X., Hong, S., Zhang, X. and Xue, Y. (2004), "Water management in the yellow river basin: background, current critical issues", Comprehensive Assessment Research Report 3, International Water Management Institute, Colombo, Sri Lanka. 
Gonçalves, J.F.J., Graça, M.A.S. and Callisto, M. (2007), "Litter decomposition in a Cerrado savannah stream is retarded by leaf toughness, low dissolved nutrients and a low density of shredders", Freshwater Biology, Vol. 52 No. 8, pp. 1440-1451.

Howe, C., Jones, R.N. and Maheepala, S. (2005), "Implications of potential climate change for melbourne's water resources”, CSIRO Urban Water, CSIRO Atmospheric Research, Melbourne.

Jakimavičius, D. and Kriaučiūnienè, J. (2013), "The climate change impact on the water balance of the Curonian Lagoon”, Water Resources, Vol. 40 No. 2, pp. 120-132.

Karamouz, M., Yazdi, M.S.S., Ahmadi, B. and Zahraie, B. (2011), “A system dynamics approach to economic assessment of water supply and demand strategies", Proceedings of the 2011 World Environmental and Water Resources Congress, pp. 1194-1203.

Khatri, K.B. and Vairavamoorthy, K. (2009), "Water Demand Forecasting for the City of the Future against the Uncertainties and the Global Change Pressures: case of Birmingham”, World Environmental and Water Resources Congress 2009: Great Rivers.

Kim, S., Kim, B.S. and Jun, H. (2014), "Assessment of future water resources and water scarcity considering the factors of climate change and social-environmental change in Han River basin, Korea", Stochastic Environmental Research and Risk Assessment, Vol. 28 No. 8, pp. 1999-2014, doi: 10.1007/s00477-014-0924-1.

Liu, C. and Zhang, S. (2002), "Drying up of the Yellow river: its impacts and counter-measures", Mitigation and Adaptation Strategies for Global Change, Vol. 7 No. 3, pp. 203-214.

MWR (2000-2012), China Water Resources Bulletin. Ministry of Water Resources (MWR), MWR, Beijing, China.

Nigel, W.A. and Ben, L.-H. (2014), "The global-scale impacts of climate change on water resources and flooding under new climate and socio-economic scenarios", Climatic Change, Vol. 122 Nos 1/2, pp. 127-140.

Protopapas, A.L., Katchamart, S. and Platonova, A. (2000), "Weather effects on daily water use in New York City", Journal of Hydrologic Engineering, Vol. 5 No. 3, pp. 332-338.

Qi, C. and Chang, N. (2011), "System dynamics modeling for municipal water demand estimation in an urban region under uncertain economic impacts", Journal of Environmental Management, Vol. 92 No. 6, pp. 1628-1641.

Shahid, S., Minhans, A. and Puan, O.C. (2014), "Assessment of greenhouse gas emission reduction measures in transportation sector of Malaysia", Jurnal Teknologi, Vol. 70 No. 4, pp. 1-8.

Shahid, S., Pour, S.H., Wang, X.-J., Shourav, S.A., Minhans, A. and Ismail, T. (2017), "Impacts and adaptation to climate change in Malaysian real estate", International Journal of Climate Change Strategies and Management, Vol. 9 No. 1, pp. 87-103.

Shahid, S., Wang, X.-J., Harun, S.B., Shamsudin, S.B., Ismail, T. and Minhans, A. (2016), "Climate variability and changes in the major cities of Bangladesh: observations, possible impacts and adaptation", Regional Environmental Change, Vol. 16 No. 20, pp. 459-471.

Simonovic, P.S. (2002), "World water dynamics: global modeling of water resources", Journal of Environmental Management, Vol. 66 No. 3, pp. 249-267.

Vörösmarty, C.J., Green, P., Salisbury, J. and Lammers, R.B. (2000), “Global water resources: vulnerability from climate change and population growth”, Science, Vol. 289 No. 5477, pp. 284-288.

Wang, X.-J., Zhang, J.-Y., Shahid, S., ElMahdi, A., He, R.-M., Wang, X.-G. and Ali, M. (2011), "Gini coefficient to assess equity in domestic water supply in the Yellow River", Mitigation and Adaptation Strategies for Global Change, Vol. 17 No. 1, pp. 65-75.

Wang, X.-J., Zhang, J.-Y., Shahid, S., ElMahdi, A., He, R.-M., Bao, Z.-X. and Ali, M. (2012a), "Water resources management strategy for adaptation to droughts in China", Mitigation and Adaptation Strategies for Global Change, Vol. 18 No. 8, pp. 923-937.

Wang, X.J., Zhang, J.Y., Ali, M., Shahid, S., He, R.-M., Xia, X.-H. and Jiang, Z. (2016b), "Impact of climate change on regional irrigation water demand in Baojixia irrigation district of China", Mitigation and Adaptation Strategies for Global Change, Vol. 21 No. 2, pp, pp. 233-247, doi: 10.1007/s11027-014-9594-z. 
IJCCSM

10,3

\section{8}

Wang, X.-J., Zhang, J.-Y., Shahid, S., Bi, S.-H., Elmahdi, A., Liao, C.-H. and Li, Y.-D. (2017), "Forecasting industrial water demand in Huaihe River Basin due to environmental changes", Mitigation and Adaptation Strategies for Global Change, pp. 1-15, doi: 10.1007/s11027-017-9744-1.

Wang, X.-J., Zhang, J.-Y., Shahid, S., ElMahdi, A., He, R.-M., Wang, X.-G. and Ali, M. (2012b), “Gini coefficient to assess equity in domestic water supply in the Yellow River", Mitigation and Adaptation Strategies for Global Change, Vol. 17 No. 1, pp. 65-75.

Wang, X.J., Zhang, J.Y., Shahid, S., Guan, E.-H., Wu, Y.-X., Gao, J. and He, R.-M. (2016a), “Adaptation to climate change impacts on water demand", Mitigation and Adaptation Strategies for Global Change, Vol. 21 No. 1, pp. 81-99, doi: 10.1007/s11027-014-9571-6.

Wang, X.-J., Zhang, J.-Y., Shahid, S., He, R.-M., Xia, X.-H. and Mou, X.-L. (2015), "Potential impact of climate change on future water demand in Yulin city, Northwest China", Mitigation and Adaptation Strategies for Global Change, Vol. 20 No. 1, pp. 1-19, doi: 10.1007/s11027-013-9476-9.

Wang, X.-J., Zhang, J.-Y., Shahid, S., Xia, X.-H., He, R.-M. and Shang, M.-T. (2014a), “Catastrophe theory to assess water security and adaptation strategy in the context of environmental change", Mitigation and Adaptation Strategies for Global Change, Vol. 19 No. No. 4, pp. 463-477, doi: 10.1007/s11027-012-9443-X.

Wang, X.-J., Zhang, J.-Y., Wang, J.-H., He, R.-M., ElMahdi, A., Liu, J.-H., Wang, X.-G., King, D. and Shahid, S. (2014b), "Climate change and water resources management in Tuwei river basin of Northwest China", Mitigation and Adaptation Strategies for Global Change, Vol. 19 No. No. 1, pp. 107-120.

YRCC (1998-2012), Yellow River Water Resources Bulletin. Yellow River Conservancy Commission, YRCC, Zhengzhou.

Zhou, S.L., McMahona, T.A., Waltonb, A. and Lewisb, J. (2000), "Forecasting daily urban water demand: a case study of Melbourne”, Journal of Hydrology, Vol. 236 Nos 3/4, pp. 153-164.

\section{Author affiliations}

Xiao-jun Wang, State Key Laboratory of Hydrology-Water Resources and Hydraulic Engineering, Nanjing Hydraulic Research Institute, Nanjing, China and Research Center for Climate Change, Ministry of Water Resources, Nanjing, China

Jian-yun Zhang, State Key Laboratory of Hydrology-Water Resources and Hydraulic Engineering, Nanjing Hydraulic Research Institute, Nanjing, China and Research Center for Climate Change, Ministry of Water Resources, Nanjing, China

Shamsuddin Shahid, Faculty of Civil Engineering, Universiti Teknologi Malaysia (UTM), Johor Bahru, Malaysia

Lang Yu, China Institute of Water Resources and Hydropower Research, Beijing, China

Chen Xie, Yellow River Conservancy Commission, Zhengzhou, China

Bing-xuan Wang, Hohai University, Nanjing, China, and

Xu Zhang, State Key Laboratory of Hydrology-Water Resources and Hydraulic Engineering, Nanjing Hydraulic Research Institute, Nanjing, China and Research Center for Climate Change, Ministry of Water Resources, Nanjing, China

\section{Corresponding author}

Xiao-jun Wang can be contacted at: xjwang@nhri.cn

For instructions on how to order reprints of this article, please visit our website:

www.emeraldgrouppublishing.com/licensing/reprints.htm

Or contact us for further details: permissions@emeraldinsight.com 